\title{
A EDUCAÇÃO ESCOLAR E A FORMAÇÃO HUMANA EM TEMPOS DE NEOLIBERALISMO: REFLEXÕES SOBRE A FORMAÇÃO DO PROFESSOR
}

Leonardo José Pinho Coimbra ${ }^{1}$ Ana Paula Ribeiro de Sousa ${ }^{2}$

\begin{abstract}
Resumo
Analisa-se nesse ensaio a formação humana e, mais especificamente, a formação dos professores no contexto da sociedade capitalista neoliberal. Se a apropriação dos bens materiais e culturais é condição para o completo desenvolvimento humano, observa-se que o processo, cada vez mais intenso, de apropriação desses bens por parte de uma pequena parcela da população, como grave obstáculo para o processo de desenvolvimento e humanização dos homens. Nesse sentido, a análise sobre a formação dos profissionais da educação, os responsáveis pela formação das demais categorias de trabalhadores, é exemplar. O tecnicismo pedagógico e as políticas atuais para formação de professores no Brasil trouxeram uma série de novos desafios que precisam ser enfrentados se quisermos construir uma educação de qualidade socialmente referenciada.
\end{abstract}

Palavras-chave: Educação. Neoliberalismo. Formação de professores.

\section{THE SCHOLL EDUCATION AND TEACHER FORMATION IN NEOLIBERALISM TIMES: REFLECTIONS ABOUT TEACHER'S FORMATION}

\begin{abstract}
This essay analysis the human's training and, more specifically, the training of teachers in the context of neoliberal capitalist society. If the appropriation of goods materials and cultural rights is a condition for the full human development of their higher mental functions, it is analyzing the process, more and more intense, the appropriation of property by a small portion of the population, as a serious obstacle to the process development and humanization of men. In this sense the formation of education professionals, responsible for the training of other categories of workers, is exemplary. The pedagogical technicality and current policies for teacher training in Brazil brought a number of new challenges that must be faced if we are to build a socially relevant quality education.
\end{abstract}

Keywords: Education. Neoliberalism. Teacher formation. 


\title{
INTRODUÇÃO
}

Os homens produzem, a cada dia, por meio de sua ação sobre a natureza e de suas relações com outros homens, as condições para a garantia da sua existência. Assim, por sua intervenção objetiva no mundo material, eles criam as condições de sua reprodução, mediante o processo de objetivação, ou seja, de materialização das necessidades que se lhes impõem, colocando-se como seu primeiro ato histórico (MARX, 1998), como condição de sua sobrevivência e de sua reprodução enquanto espécie - a produção da vida material.

Tal reprodução da vida material é possível graças à nossa atividade vital - o trabalho - por meio do qual agimos sobre o nosso corpo inorgânico - a natureza. Garantimos, dessa maneira, nossa existência e a própria existência da sociedade, pois só é possível existir enquanto ser humano no contexto de uma sociedade, uma vez que, "A minha própria existência é atividade social. Por conseguinte, o que eu próprio produzo é para a sociedade que o produzo e com a consciência de agir como ser social". (MARX, 2005a, p. 140).

Ao objetivar na natureza os produtos de suas necessidades, sejam elas as do estômago, sejam da fantasia (MARX, 2003), os homens passam a se apropriar dos conteúdos deste processo, que se desenvolve qualitativamente, à medida que as necessidades humanas se ampliam e sofisticam - transformando-se em "[...] necessidades sociais" (SAVIANI, 2012, p. 21), num infinito devenir responsável pelo seu ato de nascimento: a história, que, no entender de Marx, é um ato de nascimento que se supera. (DUARTE, 2013). Adquirindo conhecimento sobre a natureza, constroem seu processo de subjetivação, humanizam-se por intermédio da realização da sua essência genérica e universal, tendo em vista que

\begin{abstract}
Só por meio da riqueza objetivamente desenvolvida do ser humano é que em parte se cultiva e em parte se cria a riqueza da sensibilidade subjetiva humana (o ouvido musical, o olho para a beleza das formas, em resumo, os sentidos capazes de satisfação humana e que se confirmam como capacidades humanas). Certamente, não são apenas os cinco sentidos, mas também os chamados sentidos espirituais, os sentidos práticos (vontade, amor, etc.), ou melhor, a sensibilidade humana e o caráter humano dos sentidos, que vêm à existência mediante a existência de seu objeto, por meio da característica humanizada. A formação dos cinco sentidos é a obra de toda a história mundial anterior. (MARX, 2005a, p. 144).
\end{abstract}

Sendo assim, a atividade vital realizada em sociedade, em relação com outros homens, está submetida aos condicionamentos da forma que assume tal atividade em cada época e lugar, baseada no regime de propriedade dos meios sociais de produção (terra, instrumentos, técnica, conhecimento, etc.). Em uma sociedade que privatiza os meios de produção, tal atividade vital assume uma forma específica, que se coloca contra a produção do homem genérico e universal, transformando a essência humana em meio para satisfação da sua existência. O trabalho, agora alienado, "[...] inverte a relação, uma vez que o homem, enquanto ser lúcido, transforma a sua atividade vital, o seu ser, em simples meio da sua existência”. (MARX, 2005a, p. 116).

Em tais sociedades, a atividade vital humana reduz-se a mero meio de satisfação das necessidades mais básicas dos homens, em simples forma de garantia da sua sobrevivência, ficando, dessa maneira, obstaculizado o processo de humanização, de formação do ser 
genérico, de construção da individualidade para si. (DUARTE, 2013; FRIGOTTO, 2010; MARTINS, 2013; MARX, 2005a; SAVIANI, 2012).

\begin{abstract}
O homem sufocado pelas preocupações, com muitas necessidades, não tem qualquer sentido para o mais belo espetáculo; o comerciante de minerais vê apenas o seu valor comercial, e não a beleza e a natureza própria do mineral, encontra-se desprovido do sentido mineralógico. Portanto, a objetivação da essência humana, tanto do ponto de vista teórico como prático, é necessária para humanizar os sentidos do homem e criar a sensibilidade humana correspondente a toda a riqueza do ser humano e natural. (MARX, 2005a, p. 144).
\end{abstract}

Tal obstacularização se materializa nas formas desiguais de apropriação dos resultados dos processos de objetivação dos seres humanos (SAVIANI, 2012), visto que em uma sociedade classista coletiviza-se o trabalho, mas não seus produtos.

Isso posto, perguntamo-nos: Que possibilidades e que limites perpassam as práticas educativas na atualidade, as quais se efetivam sob o viés de uma sociedade capitalista neoliberal, em que o Estado se desresponsabiliza do financiamento das políticas sociais, dentre elas, a educação, e em que se hegemonizam as ideologias do Estado mínimo, fazendo recrudescerem os ataques privatistas à educação, solapando, ainda mais, o ideal progressista de socialização da cultura coletivamente produzida pela humanidade pela via da escola?

Tendo em vista que o processo de escolarização é fundamental para a humanização dos indivíduos, possibilitando a estes a formação de seus sentidos, mesmo nos limites estruturais impostos pela sociedade capitalista, pretendemos, neste artigo, analisar como as políticas educacionais formuladas nas últimas décadas, mormente à formação de professores, tem se configurado um retrocesso no sentido da formação humana, em detrimento da formação do trabalhador como mão de obra para a exploração do capital.

Desse modo, tomaremos como objeto empírico o processo de implantação das Licenciaturas Interdisciplinares na Universidade Federal do Maranhão (UFMA), a partir de 2010, com a adesão desta ao Programa de Reestruturação e Expansão das Universidades Federais - REUNI. Procuraremos demonstrar como a precarização do ensino superior e a consequente oferta de cursos aligeirados com formatos ditos "inovadores" frente aos modelos tradicionais de formação de professores, contribuem para o empobrecimento da educação escolar e a redução de suas possibilidades no que se refere a formação humana.

\title{
A EDUCAÇÃO EM UMA SOCIEDADE CLASSISTA: QUE POSSIBILIDADES E QUE LIMITES?
}

Pelo trabalho o homem se humaniza ou desumaniza ${ }^{3}$, produz e reproduz o mundo que o cerca e a si mesmo, diferenciando-se dos demais animais - visto que não só pode se adaptar às condições impostas pela natureza como pode transformá-las, segundo suas necessidades, posto que

A ação humana não é apenas biologicamente determinada, mas se dá principalmente pela incorporação das experiências e conhecimentos produzidos e transmitidos de geração a geração; a transmissão dessas experiências e 


\section{Revista HIIST'TEIDBR On-line}

conhecimentos - por meio da educação e da cultura - permite que a nova geração não volte ao ponto de partida da que a precedeu. (ANDERY, et al. 2004, p. 10).

Tal diferenciação entre homem e os demais animais se expressa também pelo fato de os homens não só transformarem a natureza, mas também transmitirem às novas gerações, o produto dos seus conhecimentos adquiridos nessas experiências - aquilo que denominamos de cultura. Essa transmissão se dá pela educação. Dessa forma, fica bem claro que a educação nasce com os homens, como uma necessidade de introduzir os novos elementos da sociedade na vida da qual farão parte; mas não apenas isso, ela também engloba os processos de formação que se orientam no sentido da produção do ser genérico, da humanização dos seres humanos. Nesse sentido, também é correto afirmar da educação o mesmo que Marx afirmou da história, ou seja, a educação também é um ato de nascimento que se supera.

Entretanto, a educação, assim como os demais fenômenos da vida em sociedade, não se dá no vácuo; ela é produto do conjunto das relações sociais da existência humana, em seu sentido mais amplo, sendo condicionada por estas relações, que são históricas, pois se desenvolvem no seio de uma determinada sociedade e de uma determinada etapa do processo de desenvolvimento humano. Logo, "[...] poucos negariam hoje que os processos educacionais e os processos sociais mais abrangentes de reprodução estão intimamente ligados". (MÉSZÁROS, 2005, p. 25).

Então, refletir sobre a educação, atualmente, é refletir, também, sobre a forma de organização da produção na sociedade capitalista contemporânea, com base na análise das influências desta forma de organização social no campo das ideias pedagógicas, que caracterizam os diversos projetos de educação em disputa nessa mesma sociedade.

Podemos afirmar que a educação nasce com os homens como condição mesma de sua reprodução, como forma de perpetuação da sociedade, de seus valores, de suas crenças, de seus conhecimentos, etc. Embora isso seja verdade, também é verdade que as sociedades estão sempre mudando, se transformando, pois não só recebemos passivamente os conteúdos da cultura, como também interferimos qualitativamente para ressignificação destes conteúdos a partir da nossa atividade sobre o mundo.

Assim, quanto mais nos apropriamos dos conhecimentos e da cultura coletivamente construídos pela humanidade, mais aptos estamos a ressignificá-los e à própria sociedade, transformando-os. Quanto mais restritos e exclusivos estão estes conhecimentos, menor serão essas possibilidades de transformação. Logo, o nosso pleno desenvolvimento cognitivo, assim como a plena democratização da sociedade, depende, pari passum, da "[...] superação do ser hominizado em direção ao ser humanizado" (MARTINS, 2013, p. 10), o que compreende a inserção de todos no mundo da cultura e dos processos formais de educação e formação, visto que,

Para que os indivíduos se insiram na história, humanizando-se, eles precisam de educação, da transmissão da cultura material e simbólica por parte de outros indivíduos. No ato educativo, condicionado pelo trabalho social, reside a protoforma do ser social, isto é, de um ser cujo desenvolvimento é condicionado pela qualidade das apropriações que realiza. (MARTINS, 2013, p. 10).

A escolarização é um dos requisitos fundamentais para o processo de democratização da sociedade, entendendo por democratização a conquista, pelo 


\title{
Revista HIIST'TEIDBR On-line
}

conjunto da população, das condições materiais, sociais, políticas e culturais que lhe possibilitem participar na condução das decisões políticas e governamentais. (LIBÂNEO, 1994, p. 34).

E não estamos superestimando o poder e a amplitude dos processos educativos formais como mecanismos de luta contra as injustiças sociais e desigualdades de classes, muito menos invertendo a tese emblemática do marxismo sobre os condicionantes entre base econômica e superestrutura ideológica. Até porque, em se tratando de método, o próprio Marx, em carta a Paul Ernst, datada de 5 de julho de 1890, já afirmava:

\begin{abstract}
A evolução política, jurídica, filosófica, religiosa, literária, artística, etc. baseia-se na evolução econômica. Porém, todas interagem e agem em relação à base econômica, não é certo, assim, que a situação econômica seja a única causa ativa e todas as outras um efeito puramente passivo. Trata-se, antes de tudo, de uma ação que muda sobre a base fundamental da necessidade econômica que, em definitivo, se impõe constantemente. (MARX apud FONTANA, 2004, p. 214, grifo nosso).
\end{abstract}

Dessa maneira, cabe tomarmos a escola como mais um palco, entre outros existentes, de luta a favor da construção de uma sociedade verdadeiramente democrática, sem perdemos de vista os seus condicionamentos e suas limitações, que se ligam ao próprio cenário econômico, isto é, à base produtiva material da existência humana. Tal relação é necessária, à guisa de coerência epistemológica, para a própria compreensão da realidade objetiva, para além das aparências fenomênicas imediatas.

Cabe salientar que, em uma sociedade classista, a educação ofertada aos trabalhadores não se orienta no sentido de construir nestes a sua máxima humanização, ao contrário, inferimos que, mesmo sendo o trabalho uma atividade formadora e constituinte do psiquismo humano, no capitalismo "[...] o que se observava era a universalização da forma social do trabalho alienado, deformador; a formação se desenvolveria como um déficit ético no capitalismo". (MAAR, 2011, p. 17).

De todo modo, ainda se faz muito atual a reflexão sobre a relevância da educação escolar para a construção de uma sociedade verdadeiramente democrática, pois, afinal, quem educa o educador? Se é verdade que um homem mudado requeira novas circunstâncias e uma nova educação, é só na práxis revolucionária que poderemos construir a "[...] coincidência da mudança das circunstâncias e da atividade humana ou automudança". (MARX, 1998, p. 100).

Diante disso, vale frisar que na lógica de uma sociedade classista e desigual, de interesses conflitantes e divergentes, a educação se realiza no seu sentido dialético, ou seja, tanto pode ter um caráter revolucionário quanto um caráter legalista e conservador. Em qualquer sociedade onde existam relações que envolvam interesses antagônicos, as ideias refletem essas diferenças, e, embora possam prevalecer os interesses das classes dominantes, a possibilidade de construção de uma outra perspectiva - contrária aos interesses das elites - encontra seu correspondente na classe trabalhadora.

E não se diga que a questão é de simplesmente aproveitar as brechas do sistema, o que nos relega à condição de eternos espectadores dos enganos do poder dominante para atuar onde ele, poder, foi incompetente. O espaço de ação 


\section{Revista HIIST'TEIDBR On-line}

existente na escola, como em cada setor ou parte da totalidade, é um espaço garantido, não pela incompetência da classe que detém o poder econômico nessa sociedade (muito embora isso também ocorra algumas vezes), mas pela existência objetiva de seu contrário, de sua negação, ou seja, daqueles que são excluídos da escola ou que nem mesmo a ela têm acesso. (MELLO, 1998, p. 14).

No presente artigo, assumimos um posicionamento político que concebe a educação como possibilidade, qual seja: direcionada à crítica de uma realidade alienada, injusta e desigual, e para a superação do modelo capitalista de sociedade, que se encaminhe para além dos "modismos" educacionais da época atual, consonantes com as perspectivas da produção capitalista neoliberal e da sociedade pós-moderna. Uma educação que vise formar o homem em sua omnilateralidade, que coloque nas mãos do indivíduo as possibilidades para guiar seu próprio destino, em suma, que vá ao encontro da liberdade. O que só se fará plenamente quando o homem superar as condições dadas, por meio da práxis ${ }^{4}$ transformadora.

Cabe destacar ainda que ambos os conceitos, o de práxis e o de liberdade, assumem, em Marx, uma dimensão concreta, material, histórica e revolucionária, superando a noção abstrata e idealista dessas categorias, pois à consciência da práxis, segundo Vázquez (1977, p. 08),

[...] chega-se superando por sua vez o ponto-de-vista limitado e mistificado da consciência idealista, e não voltando a um estágio anterior ou pré-filosófico. Nesse sentido, a destruição da atitude própria à consciência comum é condição indispensável para superar toda consciência mistificada da práxis e ascender a um ponto-de-vista objetivo, científico, a respeito da atividade prática do homem. Só assim podem unir-se conscientemente pensamento e ação.

E, no que se refere à liberdade, afirma Martins (2004, p. 60):

[...] Marx rechaça a concepção idealista, abstrata de liberdade, pela qual esta se apresenta como isenção de toda determinação ou limitação histórico-social. A liberdade não é nenhuma propriedade metafísica do homem pela qual ele possa desvincular-se do mundo real, das circunstâncias históricas.

Dessa forma, a educação que defendemos deve expressar uma pedagogia - no sentido da práxis - que está inserida em um contexto histórico-social específico e que sofre os seus condicionamentos, mas que, como mediação, pode ser mais um palco de luta contra a ideologia burguesa, portanto, uma força objetiva no tocante à possibilidade de construção de uma nova sociedade, pois, para Marx (2005, p. 151): “É certo que a arma da crítica não pode substituir a crítica pelas armas, que o poder material tem de ser derrubado pelo poder material, mas a teoria converte-se em força material quando penetra nas massas".

Mediante esse entendimento, mesmo com todas as restrições que sofre (estrutura física, falta de financiamento, falta de segurança, professores mal formados, precarização da carreira docente), se quisermos construir a crítica da sociedade capitalista, precisaremos agir contando com a escola, pois ainda "[...] há o que fazer nesta escola existente, para quem, como eu, quer torná-la menos seletiva e elitista do que ela é hoje”. (MELLO, 1998, p. 14). Entendemos, então, que a escola deve ser concebida na sua dimensão dialética, superando a concepção reprodutivista da educação, pela qual se constitui somente como instrumento de inculcação dos valores burgueses. 
Ao nos posicionarmos contra essa visão, não estamos deixando de reconhecer que a escola é, também, um espaço de reprodução, como referido acima, mas defendemos uma educação e uma escola que também são possibilidades de transformação e que visem a promover, de forma universal e democrática, a apropriação dos saberes historicamente construídos pelos homens, como instrumentos de luta contra a dominação e as desigualdades da sociedade capitalista, que se gestam na alienação do trabalho e da produção. Essa escola não pode ser outra senão a escola pública com qualidade socialmente referenciada e essa educação só pode ser uma educação pautada em uma visão socialista.

\section{A FORMAÇÃO DOS PROFESSORES SOB O ESCOPO DO CAPITALISMO NEOLIBERAL}

A formação dos indivíduos se coloca como condição para o aprimoramento de suas funções psicológicas, para seu desenvolvimento cognitivo e das suas relações interpessoais. Tal formação deve traduzir um processo intencional, objetivo e racional, planejado e executado de modo a construir "[...] em cada indivíduo singular, a humanidade que é produzida histórica e coletivamente pelo conjunto dos homens". (SAVIANI, 2005a, p. 13).

Em uma sociedade que generalizou a forma escolar como modo predominante de educação, cabe ao professor - o educador por excelência - a intermediação entre $\mathrm{o}$ conhecimento erudito e científico, produto da intervenção humana na natureza e legado universal de toda a humanidade, e os conhecimentos sincréticos dos alunos, de forma a permitir a estes últimos o desenvolvimento das suas funções cognitivas.

Porque o professor, enquanto alguém que, de certo modo, aprendeu as relações sociais de forma sintética, é posto na condição de viabilizar esta apreensão por parte dos alunos, realizando a mediação entre aluno e o conhecimento que se desenvolveu socialmente. (SAVIANI, 2005a, p. 144).

Logo, a formação dos profissionais de educação ganha relevo se quanto aos objetivos de uma educação "[...] como atividade mediadora no seio da prática social global", responsável pelo "[...] desenvolvimento e transformação das relações sociais". (SAVIANI, 2005a, p. 143). A mesma deve estar pautada na articulação dialética entre teoria e prática, entre conteúdos e métodos de ensino, sem estabelecer falsas dicotomias entre tais dimensões da prática pedagógica dos docentes, visto que “A separação destes aspectos é própria de uma lógica não-dialética, da lógica formal, pela qual se pode separar, pela abstração, um elemento do outro". (SAVIANI, 2005a, p. 144).

Pautar-se-á ainda "[...] por uma competência profissional numa perspectiva não meramente tecnicista" (MELLO, 1998, p. 43), que alia domínio dos conteúdos escolares à uma didática que favoreça a sua apropriação pelo aluno e a uma reflexão crítica e global constante da sua prática dentro da escola, e para além dela, compreendendo as relações sociais próprias do sistema capitalista, que condicionam a prática escolar. (MELLO, 1998).

No cenário atual, presenciamos as mudanças que ocorrem em consonância com a crise de um modelo de organização da sociedade capitalista, baseada nas relações de produção de tipo fordista/taylorista e no modelo keyneziano de organização do Estado, no 
qual percebemos, sob uma nova roupagem, a (re)emergência das práticas políticoeconômicas do liberalismo.

Tais ideias fazem brotar no seio da sociedade capitalista uma nova forma de organização do processo de produção, cujos pressupostos se orientam em favor de uma flexibilização nas relações de trabalho e a uma crescente necessidade em adaptar o trabalhador à presente lógica capitalista, para a qual a educação tem nítida importância, pois se caracteriza como uma forma privilegiada de inculcação de valores e concepções de mundo da classe dominante, contribuindo, desta maneira, para a reprodução/controle da força de trabalho.

Certamente esse processo reprodutivista encontra seu antagonismo na classe trabalhadora por meio de suas formas históricas de organização e luta. No entanto, há uma tendência dominante da concepção produtivista de educação, que remonta à segunda metade do século passado e popularizou uma visão de educação como formadora de capital humano, assentada nas teses de Schultz (FRIGOTTO, 2010). Tais teses são retomadas dentro do processo de flexibilização do trabalho e da formação do trabalhador para este fim.

Desse modo, podemos relacionar as mudanças que estão ocorrendo na base produtiva material ${ }^{5}$, a partir da reestruturação da produção, bem como uma nova forma de organização do trabalho (toyotismo), com as novas propostas formativas pensadas para o trabalhador nesse fim de século. Neste novo cenário será preciso formar um tipo de trabalhador mais afeito e "resiliente" ante as transformações ora em curso, o que ensejará reformas nos sistemas educacionais orientadas por políticas educacionais de caráter conservador, tecnicista e privatista. A educação passa a ser encarada como força motriz capaz de impulsionar o desenvolvimento dos países emergentes, inserindo-os, de maneira mais equânime, no competitivo mercado internacional.

É o resgate da velha teoria do Capital Humano, agora sob nova roupagem. A "sociedade do conhecimento" mascara o verdadeiro ethos desta "sociedade das ilusões" . Os discursos que reivindicam novas competências e habilidades como requisitos necessários para inserção dos trabalhadores no mercado de trabalho, acabam por desprezar a contraditória e perversa lógica em que se inserem esses trabalhadores nesse mercado. Esta lógica foi definida por Kuenzer (2005) como a "exclusão includente e a inclusão excludente".

A exclusão includente se dá no mercado de trabalho com o processo, cada vez mais intenso, de contratações precárias, temporárias, part time, etc. Já a inclusão excludente se dá na educação, pois mesmo que se consiga universalizar a educação, as novas formas de organização e gestão da produção, atreladas ao revolucionar da base técnico-científica, com a substituição de trabalho vivo por trabalho morto, promovem o desemprego em massa de trabalhadores, favorecendo, ao mesmo tempo, a exploração da força de trabalho, da qual o exército de reserva agora serve como regulador. Com isso,

[...] deixa de ser considerado um fator de crise [...] para converter-se agora em um dos elementos do processo de controle das crises que aciona o mecanismo de desaquecimento da economia como forma de mantê-la ajustada às relações sociais vigentes, comandadas pelos interesses do sistema financeiro internacional. (SAVIANI, 2005b, p. 21-22). 
Tais mudanças no processo produtivo também dispensam conteúdo cognitivo da formação dos trabalhadores em vez de acrescê-lo, esvazia sua atividade e explora com mais intensidade a força de trabalho. (KUENZER, 2005). Em outras palavras:

[...] o discurso da qualificação, como exigência para inserção no mercado de trabalho, ou como pré-requisito para a "empregabilidade", na verdade, é um discurso demagógico que deixa à margem desse processo uma grande maioria de trabalhadores, visto que o que está acontecendo efetivamente nas empresas é que, com uma parcela menor de trabalhadores e uma nova forma de organização da produção, se potencializa a exploração do trabalho, maximizando, pari passum, a extração de mais-valia. A flexibilização do trabalho, dessa forma, alimenta a maximização do lucro, onde um trabalhador agora pode assumir o controle das funções operativas de vários outros, sem, contudo, comprometer a produção. (COIMBRA, 2009, p. 37).

$\mathrm{Na}$ verdade, as funções requeridas dos trabalhadores, no contexto atual, estão no sentido de uma "[...] capacitação geral, rapidez de raciocínio, grande potencial de incorporação de informações, adaptação mais ágil, capacidade de lidar com conceitos abstratos e assim por diante" (SAVIANI, 2005b, p. 243-244); o novo rol de qualidades requeridas para o trabalhador "[...] assumem as feições de uma reforma intelectual e moral" (KUENZER, 2005, p. 79), que, indubitavelmente, retiram do trabalhador, e no nosso caso mais específico, do professor - posto que é sobre este que se colocará a responsabilidade pela formação deste trabalhador -, os conteúdos necessários para o exercício de sua "competência profissional"".

Portanto, por mais que se coloque como imperativo a qualificação e a formação do indivíduo, essa formação, para a grande maioria das pessoas, se reveste apenas de uma educação básica, geral, direcionada a preparar o trabalhador para executar operações cada vez mais simplificadas pelo complexo de "máquinas inteligentes" que agora substituem, além da força física, a própria capacidade intelectual dos trabalhadores.

Apela-se, por outro lado, para uma formação mais direcionada aos aspectos comportamentais, no sentido de "domesticar" os indivíduos aos novos padrões de produção, desenvolvendo neles atitudes mais "apropriadas" às exigências do mercado. É dessa maneira que as empresas demandam agora um trabalhador mais vinculado, mais interessado, que "vista a camisa", que seja menos resistente às mudanças e que saiba operacionalizar suas tarefas em equipe; um profissional afeito ao novo tipo de sociedade ${ }^{8}$, que esteja atento às necessidades da produção para acompanhar o desenvolvimento constante e cada vez mais veloz da ciência e da tecnologia.

Percebemos, grosso modo, que todos esses discursos, relacionados à formação e à qualificação "[...] reduzem-se fundamentalmente aos elementos básicos do capital humano: dimensões cognitivas (conhecimento abstrato) e valores, atitudes, comportamento". (FRIGOTTO, 1995, p. 102). Paradoxalmente aos discursos da qualificação, que se direcionam no sentido de cobrar do trabalhador cada vez mais habilidades cognitivas, o processo produtivo na atualidade, sob o paradigma toyotista,

[...] mostra que esta nova forma de organização e gestão do trabalho, se aparentemente amplia o conteúdo do trabalho ao substituir a linha pela célula de produção, onde um trabalhador cuida de várias máquinas, na verdade, cada vez 
mais esvazia sua atividade, reduz os requisitos de qualificação e intensifica o uso da força de trabalho, explorando-a ainda mais. (KUENZER, 2005, p. 80).

$\mathrm{Na}$ esteira de todas essas mudanças, a formação do professor terá que acompanhar as demandas gerais para a qualificação do "novo" trabalhador na sociedade capitalista neoliberal. No contexto atual, depreende-se um conjunto de propostas curriculares concebidas com o intuito de favorecer a adequação dos processos de formação, em nível superior, às mudanças do mundo do trabalho, buscando ajustar os currículos das licenciaturas ao novo contexto econômico e social.

Nesse panorama alguns aspectos passam a ser valorizados: saberes tácitos apreendidos por meio da experiência subjetiva, sendo muito difícil sua transmissão através da linguagem explícita e formalizada; conhecimentos que se apresentam ligados a vivência concreta que, muitas vezes, não são adquiridos nos processos de formação institucionalizados (escola, universidade); aqueles ligados a aspectos da personalidade, com os quais se relaciona a capacidade de abstração, de comunicação, de liderança, trabalho em equipe e outros. (CAMARGO, 2009).

Deste modo, a qualificação se dá por meio do desenvolvimento de competências, sendo priorizada a dimensão da experiência, entendendo que é necessário atribuir sentido prático aos saberes escolares. Entre as implicações deste contexto nas políticas curriculares, destacam-se: a revisão dos perfis profissionais, a redução do tempo de formação (já que os saberes tácitos são aprendidos na prática) e a ampliação dos componentes curriculares, de modo a incorporarem a dimensão prática dos processos de formação. (CAMARGO, 2009).

A tese da flexibilização curricular surge justamente para adequar os mecanismos de formação profissional ao novo contexto do processo de produção. O princípio da flexibilidade curricular insere-se no conjunto de políticas curriculares voltadas para a implementação de um novo modelo de formação em nível superior.

Paralelamente, ganhou força o uso da noção de "competência", que tem por base a ideia de que não é suficiente a um profissional ter conhecimentos sobre seu trabalho; ele necessita mobilizar conhecimentos, transformá-los em ação. Assim como, em substituição a noção de currículo mínimo, surgiu a de diretrizes curriculares, por meio de um conjunto de documentos de responsabilidade do Ministério da Educação (MEC) e do Conselho Nacional de Educação (CNE), com vistas à superação da alegada rigidez dos currículos mínimos e a assegurar a flexibilidade e a qualidade da formação.

A Lei no. 9394/96 (Lei de Diretrizes e Bases da Educação Nacional - LDBEN) determina, no inciso II do art. 53, que dispõe sobre a autonomia universitária, que cabe às Universidades: "fixar os currículos dos seus cursos e programas, observadas as diretrizes gerais pertinentes”. (BRASIL, 1996). É necessário, contudo, que se observe que a Lei no. 9.131/95, define que cabe à Câmara de Educação Superior do Conselho Nacional de Educação - "deliberar sobre as diretrizes curriculares propostas pelo Ministério da Educação e do Desporto, para os cursos de graduação". (BRASIL, 1995). Assim, o CNE passou a adotar procedimentos e diretrizes para as duas vertentes profissionais formados em nível superior: o licenciado e o bacharel. No que se refere à Licenciatura foram definidas as seguintes diretrizes: 
- $\quad$ Resolução CNE/CP 01, de 18 de fevereiro de 2002, que instituiu as Diretrizes Curriculares Nacionais para a formação de professores da Educação Básica: determina que a preparação do Professor da Educação Básica, em nível superior, deve dar-se através do Curso de Licenciatura, de graduação plena, além de afirmar que a preparação de professores para a Educação Básica deve ser realizada como um processo autônomo, em curso de licenciatura plena, numa estrutura com identidade própria (BRASIL, 2002);

- $\quad$ Resolução CNE/CP 02, de 19 de fevereiro de 2002: define a duração dos cursos de licenciatura, que deverá ser integralizada em, no mínimo 03 (três) anos letivos e ocorrer através do desenvolvimento de uma carga horária mínima de 2.800 horas, organizadas da seguinte forma: I - 400 (quatrocentas) horas de prática como componente curricular, vivenciadas ao longo do curso; II - 400 (quatrocentas) horas de estágio curricular supervisionado a partir do início da segunda metade do curso; III - 1800 (mil e oitocentas) horas de aulas para os conteúdos curriculares de natureza científico-cultural; IV - 200 (duzentas) horas para outras formas de atividades acadêmico-científico-culturais, que passa a destinar mais de um terço da carga horária a atividades de natureza "prática" nos cursos de licenciatura (BRASIL, 2002).

Outros mecanismos legais se destacam na definição da política curricular para os cursos de graduação no sentido de favorecer a flexibilização curricular e a definição de itinerários formativos diversos em contraposição à noção de currículo mínimo, como é o caso do Parecer CNE/CES no. 776/97, que trata das orientações para as diretrizes curriculares para os cursos de graduação, que defende o enxugamento dos cursos, sem descuidar de uma sólida formação geral ao lado da formação diferenciada; valorização das atividades de extensão e pesquisa, que passam a valer créditos para os discentes nelas envolvidos; valorização, no interior do currículo, de atividades de extensão, monitoria, iniciação científica e outras, até então consideradas extracurriculares; revisão da fixação de currículos mínimos, alegando rigidez excessiva e prolongamento desnecessário de sua duração.

De acordo com Camargo (2009), a flexibilização curricular introduzida nos cursos de graduação, promoveu, além do enxugamento do currículo dos cursos, com a redução da carga horária, o aproveitamento de atividades diversas desenvolvidas pelos alunos, como monitoria, participação em projetos de ensino, pesquisa e extensão, estágios, cursos de curta duração relacionados a áreas de interesse do aluno, seminários, palestras ou laboratórios/oficinas, promovendo uma diversificação no itinerário formativo dos cursos que se reflete no perfil de saída do aluno.

No entanto, apesar das críticas, essa perspectiva tem assumido posição hegemônica nos discursos e nos processos de formação docente. Acentuado pelo caráter de obrigatoriedade em atender as diretrizes curriculares, muitos cursos de licenciatura tiveram seus projetos reformulados e outros foram elaborados nessa perspectiva.

\section{A FORMAÇÃO DE PROFESSORES SOB O ESCOPO DO PROJETO CAPITALISTA NEOLIBERAL: O CASO DAS "NOVAS" LICENCIATURAS DA UFMA}


As "novas" Licenciaturas Interdisciplinares foram criadas na Universidade Federal do Maranhão - UFMA, atreladas ao Programa de Apoio a Planos de Reestruturação e Expansão das Universidade Federais (REUNI). O REUNI surgiu como iniciativa governamental em 2007, tendo como principal objetivo "[...] ampliar o acesso e permanência na educação superior" (Brasil, 2010), tendo sido instituído pelo Decreto $n^{\circ}$ 6.096, de 24 de abril de 2007, sendo uma das ações integrantes do Plano de Desenvolvimento da Educação (PDE).

O REUNI consiste na expansão do ensino superior público, com poucos recursos,
e pela utilização máxima da capacidade de operação das IFES. Através do REUNI,
o governo -incentiva as IFES a firmarem contratos de gestão, por meio do
estabelecimento de termos de compromisso, pelos quais recebem verbas públicas
pelo cumprimento das metas assumidas, dentro de prazos estabelecidos e mediante
indicadores quantitativos. A pretensão do governo é atingir um aumento
substancial de ingressantes nas IFES e tem como metas principais: a elevação da
taxa de conclusão dos alunos para 90\% e o aumento da relação aluno/professor
para 18. (COIMBRA; SOUSA, 2015, p. 146-147).

A UFMA foi uma das primeiras universidades brasileiras a aderir ao REUNI, já em novembro de 2007, através da Resolução do seu Conselho Superior (CONSUN) no 104 , de 30/11/2007. Com um aporte substancial de recursos, da ordem de R 121 milhões até o ano de 2012, a UFMA "pactuou” um acordo com o Ministério da Educação (MEC) que previa, dentre outras:

[...] a ampliação das vagas de ingresso por meio da criação de 1.580 novas vagas nos cursos de graduação, 1.100 vagas para novos cursos e 480 para cursos existentes, sendo1050 vagas noturnas e 530 diurnas, contratação de 328 novos professores, 182 servidores técnico-administrativos, elevação progressiva, até o final do Programa, da relação professor/aluno (RAP) em 1:18, redução das taxas de evasão e alcance da meta de conclusão de $90 \%$ nos cursos de graduação, ocupação das vagas ociosas, pelo estabelecimento de regras mais flexíveis de ingresso, avaliação e mobilidade estudantil. (COIMBRA; SOUSA, 2015, p. 150).

Além disso, de forma a atender as diretrizes do REUNI, as Universidades Federais deveriam se comprometer com as metas voltadas à reestruturação da arquitetura acadêmica a fim de melhorar o processo formativo na graduação, especialmente: a) revisão da estrutura acadêmica, com reorganização dos cursos de graduação e atualização de metodologias de ensino-aprendizagem, buscando a constante elevação da qualidade; e b) diversificação das modalidades de graduação, preferencialmente não voltadas à profissionalização precoce e especializada.

Nessa direção, situa-se a criação de cursos de graduação com formatos alternativos aos modelos convencionais em todo Brasil, nos quais se inserem os cursos de Bacharelados Interdisciplinares (BIs) e Licenciaturas Interdisciplinares (LIs). A criação desses cursos está diretamente relacionada ao processo de expansão da rede de universidades federais ${ }^{9}$, no intuito de ampliar e interiorizar a oferta de vagas nas instituições já consolidadas e na criação de novas unidades, conforme o Parecer CNE/CES no. 266/2011.

Tal iniciativa mobilizou grande contingente de universidades que aderiram ao Reuni para criação de cursos de Licenciaturas Interdisciplinares, dentre elas, muitas universidades novas, criadas no contexto do programa de expansão das IFES. Entre as Universidades 
envolvidas nessa iniciativa de criação e normatização das LIs e que incluem essa modalidade de curso dentro dos seus projetos de extensão e reestruturação, estão: a Universidade Federal do Oeste do Pará - UFOPA, Universidade Federal do Pará - UFPA, Universidade Federal do Mato Grosso - UFMT, Universidade Federal da Integração Luso Afro-brasileira UNILAB, Universidade Federal do Maranhão - UFMA, Universidade Federal dos Vales do Jequitinhonha e Mucuri - UFVJM, Universidade Federal de Roraima - UFRR, Universidade Federal do Pampa - UNIPAMPA e Universidade Federal do ABC - UFABC.

Hoje, possuem cursos de Licenciatura Interdisciplinares, em funcionamento, as seguintes universidades: Universidade Federal do Maranhão, Universidade Federal de Roraima, Universidade Federal do Mato Grosso, Universidade Federal dos Vales de Jequitinhonha e Mucuri, Universidade Federal de Juiz de Fora, Universidade Federal do ABC, Universidade Federal do Oeste do Pará, UNILAB, Universidade Federal da Bahia, Universidade Federal do Pampa, Universidade Federal do Paraná, Universidade Federal da Integração Latino-americana, Universidade Federal da Fronteira Sul.

Portanto, percebemos que a proliferação deste tipo de curso é uma tendência nacional que se deve não apenas ao processo de expansão em curso, como também atende as diretrizes para a reformulação do ensino superior em nível mundial, sobretudo a partir da Conferência Mundial de Educação Superior da UNESCO, realizada em Paris, em 1998, e do Processo de Bolonha, de 1999, na medida em que os egressos dessa categoria de cursos desenvolvem competências, habilidades e conhecimentos gerais necessários aos postos de trabalho que requerem educação superior em uma grande área do conhecimento, mas não formação profissional específica.

Conforme afirma Sanfelice (2010, p. 34), tratando das diretrizes das agências internacionais e fóruns mundiais e regionais para a formação de professores:

\begin{abstract}
Os docentes devem aprender a adaptarem-se às mudanças permanentes no currículo e nos métodos. Como a atual formação do docente não os prepara para tanto, nem para acompanhar a evolução permanente do conhecimento, faz-se necessária a formação continuada para que ele tenha autonomia e seja responsável pelo seu trabalho. Também não lhe pode faltar a criatividade, para que se constitua em um guia do aluno que constrói o seu próprio conhecimento. É necessário que saiba trabalhar em equipe e que sua formação tenha sido prática.
\end{abstract}

Outro aspecto interessante apontado por este autor quanto às orientações dos organismos internacionais para a formação de professores é que estes devem ser responsáveis por sua formação permanente, arcando, inclusive, com o sucesso e o fracasso de sua intervenção educativa no que concerne ao rendimento dos alunos. Nesse sentido, aponta que,

\begin{abstract}
A proposta agora, de uma formação docente permanente, o responsabiliza por obtê-la. Acrescenta também a ideia que o obriga a estabelecer vínculos com a comunidade e se tornar o responsável pela aprendizagem dos alunos, incluindo aqueles de menor rendimento. (SANFELICE, 2010, p. 34).
\end{abstract}

Desse modo, ganha força a ideia de que a formação do professor deve ser permanente e se consolidar na prática, de acordo com os desafios e peculiaridades da mesma. 
$\mathrm{Na}$ Universidade Federal do Maranhão, como forma de materializar as metas "pactuadas" com o MEC, as novas Licenciaturas Interdisciplinares ${ }^{10}$ foram criadas $^{11}$, unicamente nos campi da UFMA localizados fora da sede, ou seja, em municípios do interior do Estado, contemplados com o processo de expansão em função do atendimento às metas do REUNI, no que tange ao processo de interiorização da universidade, com a maioria dos seus cursos funcionando no período noturno, como forma de oportunizar aos trabalhadores da zona rural o acesso ao ensino superior. Isso justifica a implementação de cursos menos onerosos para a universidade e com grande apelo social, através de um projeto que pretende a flexibilização da formação de professores, de modo a atender, mediante cursos interdisciplinares, a carência de professores de diversas disciplinas das grandes áreas do conhecimento na educação básica.

De acordo com a Profa. Iran de Maria Leitão Nunes, componente da equipe da PróReitoria de Ensino da UFMA, à época da elaboração dos projetos dos cursos de Licenciatura Interdisciplinares:

\begin{abstract}
Ampliando e interiorizando suas ações em prol da formação docente é que a Universidade Federal do Maranhão (UFMA) criou os Cursos de Licenciaturas em Ciências Humanas, Ciências Naturais e Linguagens e Códigos, em seis dos municípios maranhenses: Bacabal, Codó, Grajaú, Imperatriz, Pinheiro e São Bernardo. São Cursos de formação interdisciplinar, por competências e presencial, de professores para atuarem, mais especialmente, nos anos finais do Ensino Fundamental, ofertados no turno noturno. (NUNES, 2014, p. 383).
\end{abstract}

Dentre os argumentos que justificam a proposta de criação das LIs na UFMA, destaca-se a necessidade de formação de professores para atuar na educação básica, em todas as áreas do conhecimento, como um dos "problemas crônicos" (NUNES, 2014, p. 382), da educação brasileira, tendo como agravante "a má formação docente". (NUNES, 2014, p. 382). Além disso, aponta-se que a formação interdisciplinar atende as atuais diretrizes curriculares para a educação básica, que prevê a organização do currículo com base em áreas de conhecimento e não em formato disciplinar.

Também justificam a opção pelas LIs por conta da limitação de recursos da universidade para ofertar licenciaturas específicas presenciais de todas as áreas de conhecimento em todos os novos campi, e que, portanto, seria mais viável, do ponto de vista da relação custo-benefício, a criação de apenas um curso que contemple todas as disciplinas das diferentes áreas do conhecimento, após os quais, em apenas três anos de formação inicial, os egressos estariam "aptos" à docência de todas as disciplinas daquela área.

Em que pese as "boas intenções" anunciadas, como a flexibilização e a atualização dos cursos de formação de professores às atuais diretrizes curriculares, superando a rigidez dos currículos mínimos e os modelos de formação do tipo " $3+1$ " 12, tais licenciaturas reproduziram a lógica de formação de professores em um menor tempo, com mais eficiência e eficácia, com contenção de recursos e limitação de gastos. Se a Resolução CNE/CP 02, de 19 de fevereiro de 2002, definiu como tempo mínimo de duração dos cursos de licenciatura em 2.800 horas, as novas Licenciaturas Interdisciplinares assumiram essa prescrição in limine, pois em seu Projeto Político-Pedagógico estabeleceu, originalmente, ${ }^{13}$ que o tempo de duração das licenciaturas se dará em 2.880 horas. 
Outro aspecto dessa formação se traduz no seu currículo, o qual, em nome da interdisciplinaridade e da flexibilização, assume uma característica aglutinadora e reducionista e pretende formar o professor para atuar nas séries finais do ensino fundamental, no tempo mínimo estabelecido pelo CNE, nas quatro disciplinas da áreas do conhecimento das Ciências Humanas (Geografia, História, Sociologia e Filosofia) - em se tratando da Licenciatura em Ciências Humanas - e nas três disciplinas áreas do conhecimento das Ciências Naturais (Física, Química e Biologia) -, em se tratando da Licenciatura em Ciências Naturais.

Para fazer frente a essa empreitada, foram priorizados os conteúdos das disciplinas específicas da área de conhecimento do curso, em detrimento dos conteúdos de formação pedagógica, que foram reduzidas e aglutinadas em apenas algumas disciplinas, para que se tivesse mais espaço para as matérias específicas das áreas de formação ${ }^{14}$.

Dessa maneira, disciplinas como Filosofia da Educação e Sociologia da Educação, que geralmente possuem uma carga horária de 60 horas semestrais em cursos de licenciaturas "convencionais", foram aglutinadas e reduzidas à disciplina de Fundamentos SócioFilosóficos da Educação, com 60 horas semestrais. O mesmo aconteceu com a disciplina de História da Educação e Política Educacional, que agora, aglutinadas e reduzidas, denominam-se História e Política Educacional, com 60 horas por semestre. Essa perspectiva contraria diretamente uma concepção mais crítica de formação de professores, em que tais conteúdos são centrais, conforme afirmam Saviani e Duarte (2012, p. 16): "Mas o conteúdo da filosofia é a história, isto é, a produção da própria existência humana no tempo. Assim podemos concluir que a filosofia e a história da educação constituem o núcleo duro da formação de professores".

Outro exemplo disso se verifica no caso da Licenciatura em Ciências Naturais, que estabelece a disciplina de Didática com apenas 45 horas semestrais. Nesse caso específico, o recrudescimento da lógica pragmática que dispensa as disciplinas que não endossam o eixo formativo das áreas das ciências naturais se reveste de maior intensidade, pois nesses cursos não há sequer uma disciplina da área das humanidades - Filosofia, Psicologia ou Sociologia - o que sinaliza para mais uma deficiência no processo formativo destes professores.

Mesmo que o Projeto Político-Pedagógico original já esteja na sua terceira reformulação ${ }^{15}$, tais pressupostos se mantiveram inalterados, consolidando a lógica reificadora, desumanizada, tecnicista e reducionista da formação de professores nesses cursos. No currículo atual, com apenas mais um ano de disciplinas específicas ("núcleo de disciplinas específicas"), os discentes poderão lecionar no ensino médio em uma das disciplinas da área do curso. Inaugura-se na universidade a precarização exponencial da formação de professores, uma vez que agora, com o acréscimo de apenas um ano de disciplinas específicas, as LIs formarão o professor para atuar também no ensino médio, o que, na nossa visão, além de reforçar a precarização da formação destes profissionais, reduz ainda mais a já insuficiente carga horária mínima dos cursos de licenciatura interdisciplinar, segmentada entre a formação "interdisciplinar", em três anos, para ministrar aulas em todas das disciplinas da área do curso no ensino fundamental do $6^{\circ}$ ao $9^{\circ}$. ano, e uma formação "disciplinar", em um ano, para ministrar aulas de uma das disciplinas da área do curso no ensino médio. 
Portanto, uma contradição flagrante das Licenciaturas Interdisciplinares (LIs) está justamente no termo que as adjetiva, pois, apesar de trazerem a denominação de "Interdisciplinares", o currículo dos diversos cursos é uma amálgama sectária e fragmentada das diversas áreas que se "espremem" e digladiam em uma base geral dita "interdisciplinar" de três anos, acrescido de mais um ano de disciplinas específicas (disciplinar). Conforme a $2^{a}$. Versão do Projeto Pedagógico das LIs:

Dessa forma, o projeto político-pedagógico baseia-se numa matriz curricular disciplinar sem perder de vista a interdisciplinaridade, amplia a área de atuação profissional do egresso para o Ensino Médio, adota o regime acadêmico existente na Universidade e se constitui numa formação interdisciplinar conexa a uma formação específica, fortalecendo o perfil profissional do egresso do curso. (UFMA, 2013, p. 7).

Além de uma indefinição quanto ao perfil do curso (disciplinar, multidisciplinar ou interdisciplinar), o desenho curricular proposto acarreta sérias fragilidades no percurso formativo dos discentes, a ponto de que, em alguns casos, o egresso que atuará no segundo segmento do ensino fundamental $\left(6^{\circ}\right.$ ao 9 ano $)$, na disciplina de Geografia, por exemplo, só ter visto, ao longo do seu processo formativo no curso de Ciências Humanas, apenas cinco disciplinas de 60 horas na área específica de Geografia. O mesmo acontece em todas as disciplinas que não se constituem na "ênfase" do curso, um alijeiramento da formação nas demais disciplinas às quais o egresso pode vir a lecionar do $6^{\circ}$. ao $9^{\circ}$. ano do ensino fundamental, comprometendo ainda mais a qualidade do ensino nesse segmento da educação básica.

Essa deficiência pode ser evidenciada, por exemplo, na matriz curricular do curso de Licenciatura Interdisciplinar em Ciências Humanas, cuja ênfase é em Sociologia, onde predominam das disciplinas a área de sociologia, no núcleo de formação específica, em detrimento das demais disciplinas da área (geografia, história e filosofia), limitadas ao núcleo de formação básica "interdisciplinar".

Quadro 1 - Matriz Curricular do Curso de Licenciatura em Ciências Humanas com Ênfase em Sociologia

(continua)

\begin{tabular}{|l|l|l|l|}
\hline \multicolumn{4}{|c|}{ NÚCLEO DE FORMAÇÃO BÁSICA } \\
\hline \multirow{2}{*}{ DISCIPLINAS OBRIGATÓRIAS } & \multicolumn{2}{l|}{ Carga horária } & \multirow{2}{*}{ PECC } \\
\cline { 2 - 3 } & Teórica & Prática & \\
\hline INTRODUÇÃO À HISTÓRIA & $\mathbf{6 0}$ & -- & -- \\
\hline FUNDAMENTOS DE GEOGRAFIA & $\mathbf{6 0}$ & -- & -- \\
\hline INTRODUÇÃO À SOCIOLOGIA & $\mathbf{6 0}$ & -- & -- \\
\hline INTRODUÇÃO À FILOSOFIA & $\mathbf{6 0}$ & -- & -- \\
\hline NOÇÕES DE CARTOGRAFIA & $\mathbf{6 0}$ & -- & $\mathbf{1 5}$ \\
\hline CULTURA, IDENTIDADE E DIVERSIDADE & $\mathbf{6 0}$ & -- & $\mathbf{1 5}$ \\
\hline ANTROPOLOGIA FILOSÓFICA & $\mathbf{6 0}$ & -- & -- \\
\hline HISTÓRIA DA EUROPA I & $\mathbf{6 0}$ & -- & $\mathbf{1 5}$ \\
\hline HISTÓRIA DA EUROPA II & $\mathbf{6 0}$ & -- & $\mathbf{1 5}$ \\
\hline
\end{tabular}




\section{Revista HIISTESIDBR On-lime}

ISSN: 1676-2584

Artigo

doi: $10.20396 /$ rho.v17i3.8645853

Quadro 1 - Matriz Curricular do Curso de Licenciatura em Ciências Humanas com Ênfase em Sociologia

\begin{tabular}{|c|c|c|c|}
\hline \\
\hline $\begin{array}{l}\text { PRODUÇÃO E ORGANIZÇÃO DO ESPAÇO AGRÁRIO E } \\
\text { URBANO BRASILEIRO }\end{array}$ & 60 & -- & 15 \\
\hline SOCIOLOGIA CLÁSSICA & 60 & -.- & 15 \\
\hline ÉTICA E FILOSOFIA AMBIENTAL & 45 & -- & 15 \\
\hline HISTÓRIA DO BRASIL E DO MARANHÃO COLONIAL & 45 & -.- & 15 \\
\hline FUNDAMENTOS DE GEOLOGIA E GEOMORFOLOGIA & 45 & -- & 15 \\
\hline SOCIOLOGIA CONTEMPORÂNEA & 45 & -.- & 15 \\
\hline FILOSOFIA POLÍTICA & 45 & -- & 15 \\
\hline HISTÓRIA DA AMÉRICA COLONIAL & 45 & -- & 15 \\
\hline $\begin{array}{l}\text { TEORIA DO CONHECIMENTO E FILOSOFIA DAS } \\
\text { CIÊNCIAS }\end{array}$ & 60 & -- & -- \\
\hline HISTÓRIA DA ÁFRICA & 45 & -- & 15 \\
\hline $\begin{array}{l}\text { FUNDAMENTOS DE CLIMATOLOGIA E } \\
\text { HIDROGRAFIA }\end{array}$ & 45 & -- & 15 \\
\hline ESTADO E SOCIEDADE & 45 & -- & 15 \\
\hline SEMINÁRIO DE TRABALHO FINAL DE CURSO I & 60 & -- & -- \\
\hline PRÁTICA E ANÁLISE DO LIVRO DIDÁTICO & -- & -- & $\mathbf{6 0}$ \\
\hline PRÁTICA DO ENSINO DAS CIÊNCIAS HUMANAS & -- & -- & $\mathbf{6 0}$ \\
\hline \multicolumn{4}{|c|}{ NÚCLEO DE FORMAÇÃO PEDAGÓGICA } \\
\hline $\begin{array}{l}\text { FUNDAMENTOS FILOSÓFICOS E SOCIOLÓGICOS DA } \\
\text { EDUCAÇÃO }\end{array}$ & 60 & -- & 15 \\
\hline PSICOLOGIA DA EDUCAÇÃO & 60 & -- & 15 \\
\hline $\begin{array}{l}\text { TECNOLOGIAS DA INFORMAÇÃO APLICADAS AO } \\
\text { ENSINO }\end{array}$ & 60 & -- & 15 \\
\hline $\begin{array}{l}\text { DIDÁTICA E ORGANIZAÇÃO DO TRABALHO } \\
\text { ESCOLAR }\end{array}$ & 60 & -- & 15 \\
\hline HISTÓRIA E POLÍTICA EDUCACIONA & 60 & -- & -- \\
\hline EDUCAÇÃO PARA A DIVERSIDADE & 45 & -- & 15 \\
\hline LIINGUA BRASILEIRA DE SINAIS (LIBRAS) & 45 & -- & 15 \\
\hline \multicolumn{4}{|c|}{ NÚCLEO DE FORMAÇÃO ESPECÍFICA } \\
\hline EPISTEMOLOGIA DAS CIÊNCIAS SOCIAIS & 60 & -- & -- \\
\hline SEMINÁRIO DE TCC II & 60 & -- & --- \\
\hline SOCIOLOGIA DO TRABALHO & 60 & -- & --- \\
\hline EDUCAÇÃO, CULTURA E SOCIEDADE & 60 & -- & -- \\
\hline SOCIEDADE E AMBIENTE & 60 & -- & --- \\
\hline METODOLOGIA DO ENSINO DE SOCIOLOGIA & 60 & -- & --- \\
\hline TEORIA SOCIAL CRÍTICA & 60 & -- & -- \\
\hline PENSAMENTO SOCIAL BRASILEIRO & 60 & -- & -- \\
\hline SOCIOLOGI & 60 & - & \\
\hline
\end{tabular}

Fonte: Projeto Político-Pedagógico do Curso de Licenciatura Interdisciplinar com ênfase em Sociologia Campus Bacabal (UFMA, 2013).

Nota: adaptado pelos autores. 
Consagra-se, dessa forma, a lógica smithiana de educação em doses homeopáticas para a classe trabalhadora e reitera-se a formação precarizada dos profissionais de educação, num processo que esvazia sua qualificação, ao mesmo tempo que diminui o tempo destinado à formação teórica nas disciplinas básicas para o exercício do magistério, o que vem corroborar a reprodução dos péssimos índices educacionais do País, onde a maioria da população entra e sai do sistema público de ensino sabendo, basicamente, decodificar os sinais da linguagem e as operações básicas da matemática.

\section{CONSIDERAÇÕES FINAIS}

A formação dos homens é condição sine qua non para a construção de sua individualidade, para o seu desenvolvimento cognitivo pleno, para a superação das limitações dos sentidos humanos "[...] encarcerados sob a grosseira necessidade prática" (MARX, 2005a, p. 144) e a construção da "[...] sensibilidade subjetiva humana". (MARX, 2005a, p. 143). Se é verdade que, como afirma Martins (2013, p. 293), “[...] o maior contributo da educação escolar à transformação social reside na formação de indivíduos capazes de, por suas ações práticas e intencionalmente projetadas, transformá-las", é só com uma educação de qualidade socialmente referenciada que poderemos formar cidadãos para este fim precípuo.

No cenário atual, presenciamos uma lógica de desqualificação profissional do trabalhador que se dá com o recrudescimento de uma educação tecnicista, que reduz cada vez mais os conteúdos cognitivos dos processos de formação dos trabalhadores. Na formação do educador, esse processo se intensifica com cursos de licenciatura que reproduzem a lógica formativa da sociedade neoliberal. Tal processo tem levado a iniciativas de criação de cursos com algumas características comuns: curta duração, currículos fragmentados, disciplinas reduzidas e aglutinadas, estruturas físicas precárias, etc. Esse quadro compõe o atual cenário em que a formação dos profissionais de educação sofre grave retrocesso. O REUNI foi um grande impulsionador dessas iniciativas, estimuladas mediante contratos de gestão que vinculavam o cumprimento de determinadas metas relacionadas a reestruturação e expansão das IFES aos investimentos orçamentários da união.

Reverter esse quadro é imprescindível, se queremos transformar a lógica reducionista e tecnicista que tem dominado os currículos e as propostas pedagógicas na atualidade. Nesse sentido, cabe a defesa de uma pedagogia que se oriente para uma formação que supere todo tipo de modismo educacional que deslegitime o saber e os conhecimentos clássicos como orientadores da prática pedagógica do professor. Assim sendo, defendemos uma pedagogia que se direcione para a formação dos,

[...] comportamentos complexos culturalmente instituídos - com a formação das funções psíquicas superiores -, (que) radica a afirmação do ensino sistematicamente orientado à transmissão dos conceitos científicos, não cotidianos, tal como preconizado pela pedagogia histórico-crítica". (MARTINS, 2013, p. 07).

Portanto, sem dissociar nosso objeto - a formação de professores - de uma perspectiva crítica e revolucionária da educação, relacionada a uma perspectiva crítica e revolucionária em relação à sociedade, tal como formulada por Saviani (2005a) por meio da 
Pedagogia Histórico-crítica, reafirmamos a necessidade de socialização dos conteúdos da cultura, do conhecimento como meio de produção ${ }^{16}$ através da escola, como um elemento universalizante das lutas sociais. Para tanto, é necessário elevar o nível de formação das classes subalternas, por meio da melhoria da qualidade da escola pública, na qual se insere a melhoria da qualidade da formação do professor, no sentido de

[...] retomar vigorosamente a luta contra a seletividade, a discriminação e o rebaixamento do ensino das classes populares. Lutar contra a marginalidade através da escola significa engajar-se no esforço de garantir aos trabalhadores um ensino de melhor qualidade possível nas condições históricas atuais. (SAVIANI, 2007, p. 31).

Nessa perspectiva, é relevante ressaltar a importância do processo de formação do professor e até reconhecer a centralidade dessa bandeira no âmbito das políticas educacionais. No entanto, sabemos que a perspectiva predominante nas políticas e práticas voltadas para a formação docente caminham na contramão de um horizonte emancipador, com vista à articulação entre compromisso político e competência técnica, no sentido de uma práxis revolucionária, o que torna o desafio de promover uma educação por meio da qual seja possível a transformação da sociedade vigente mais espinhoso.

No entanto, no que tange à formação de professores, é preciso enfatizar os condicionantes estruturais da educação numa sociedade de classes, que evidenciam que o desafio da formação de professores transcende a questão acadêmica; são determinantes de uma realidade material que impõe amplos os obstáculos para a aquisição, pelos subalternos, dos conhecimentos técnico-científicos que possibilitem a elevação de sua visão de mundo. Esses elementos são destacados pelo Banco Mundial (2014) numa descrição do perfil dos professores na América Latina:

- Eles têm baixos incentivos salariais. Seu nível de remuneração mensal em 2010 era entre $10 \%$ e $50 \%$ mais baixo do que outros profissionais "equivalentes", e essa relação se manteve ao longo dos anos 2000.

- Eles possuem mais educação formal do que outros profissionais e técnicos, porém iniciam seus estudos acadêmicos com um nível de conhecimento inferior ao conjunto total de estudantes do ensino superior; $75 \%$ são mulheres

- Os estudantes que se especializam em educação pertencem a um nível socioeconômico mais baixo e têm maior probabilidade de serem universitários de primeira geração (cujos pais não possuem um diploma de ensino superior).

- A força de trabalho docente da região está envelhecendo. Em alguns países, um professor médio tem mais de 40 anos.

- Embora muitos países da região estejam produzindo uma oferta excedente de novos professores, ainda é difícil encontrar docentes adequados ao ensino médio de matemática e ciências, além de professores bilíngues de alta qualidade (língua espanhola e indígena) nas áreas rurais.

Obviamente, o Banco Mundial não questiona ou não explicita os fenômenos estruturais responsáveis por essa situação, mas aponta iniciativas que poderiam minimizar o problema, por exemplo, o recurso às novas tecnologias da informação e comunicação para 
reduzir o tempo e elevar a aprendizagem dos alunos. Outras soluções semelhantes formuladas pelos organismos internacionais quanto a formação de professores nos países periféricos já são conhecidas, conforme pontuado por Sanfelice (2010) e reafirmadas no relatório do Banco Mundial (2014):

- Políticas para recrutar melhores professores.

- Programas para formar ou desenvolver as habilidades dos professores que já estão em atividade.

- Maiores incentivos para motivar um desempenho de alto nível, que irão tornar a profissão mais atraente e seletiva ao longo do tempo.

Portanto, podemos perceber que a problemática da formação de professores se articula dialeticamente com a realidade objetiva, de modo que, na prática, tende a reproduzir os indicadores negativos constatados pelo Banco Mundial em seu relatório, aliados a políticas educacionais que permitem a continuidade da situação de precariedade da formação de professores. O processo de expansão do ensino superior em curso, impulsionado por políticas como o REUNI, que induzem a precarização do ensino e a certificação em larga escala nas universidades públicas, certamente contribuem para a reprodução dos fatores estruturais que condicionam a formação e o trabalho docente no Brasil.

Entretanto, tendo em vista a contradição dialética que articula o desenvolvimento da prática social, a problemática da formação de professores na sociedade contemporânea reflete o dilema da escola na sociedade capitalista, na medida em que, atendendo a uma necessidade do capital no que tange ao aprimoramento da formação técnica da força de trabalho, ao mesmo tempo, possibilita aos trabalhadores o acesso aos meios de produção, tornando possível a apropriação coletiva do saber. Logo, é necessário o acionamento de mecanismos de rebaixamento da qualidade da escola pública para que o acesso ao conhecimento não se torne uma ameaça real ao processo de dominação capitalista, pois, ao mesmo tempo que tomam consciência da realidade concreta, os indivíduos tornam-se capazes de objetivar a transformação da realidade. Concordando com Saviani (2005, p. 80), tal contribuição da escola será tão mais eficaz quanto mais o professor for capaz de compreender os vínculos da educação com a prática social global, de modo a contribuir com o processo de instrumentalização ${ }^{17}$ dos alunos para a compreensão e atuação crítica e revolucionária no âmbito desta prática social.

\section{REFERÊNCIAS}

ANDERY, M. A. P. A. et al. Para compreender a ciência: uma perspectiva histórica. 13. ed. Rio de Janeiro: Garamond; São Paulo: Ed. da EDUC, 2004.

BANCO MUNDIAL. Professores excelentes: como melhorar a aprendizagem dos estudantes da América Latina e Caribe. Washington, DC, 2014. Disponível em: <http://www.worldbank.org/content/dam/Worldbank/Highlights\%20\&\%20Features/lac/LC 5/Portuguese-excellent-teachers-report.pdf.>. Acesso em: 21 set. 2017. 
BRASIL. Lei 9.131, de 24 de novembro de 1995. Altera dispositivos da Lei $\mathrm{n}^{\circ}$ 4.024, de 20 de dezembro de 1961, e dá outras providências. Disponível em: <https://presrepublica.jusbrasil.com.br/legislacao/108165/lei-9131-95.>. Acesso em: 20 jan. 2017.

BRASIL. Lei 9.394, de 20 de dezembro de 1996. Estabelece as diretrizes e bases da educação nacional. Disponível em:

<http://www.planalto.gov.br/ccivil_03/leis/L9394.htm.>. Acesso em: 20 jan. 2017.

BRASIL. Ministério da Educação. Conselho Nacional de Educação. Câmara de Educação Superior. Parecer CNE/CES no. 266. Referenciais orientadores para os Bacharelados Interdisciplinares e Similares das Universidades Federais. Diário Oficial, Brasília, DF, seção 1, p. 16, 14 out. 2011.

BRASIL. Ministério da Educação. Conselho Nacional de Educação. Câmara de Educação Superior. Parecer CNE/CES 776/97, de 3 de novembro de 1997. Orientação para as Diretrizes Curriculares dos cursos de graduação. Brasília, DF, 1997. Disponível em: <http://portal.mec.gov.br/setec/arquivos/pdf/PCNE776_97.pdf.>. Acesso em: 20 jan. 2017.

BRASIL. Ministério da Educação. Conselho Nacional de Educação. Resolução CNE/CP no. 01, de 18 de fevereiro de 2002. Diretrizes Curriculares Nacionais para a formação de professores da Educação Básica, em nível superior, curso de licenciatura, de graduação plena. Disponível em: <http://portal.mec.gov.br/seesp/arquivos/pdf/res1_2.pdf.>. Acesso em: 20 jan. 2017.

BRASIL. Ministério da Educação. Conselho Nacional de Educação. Resolução CNE/CP no. 01, de 30 de setembro de 1999. Dispõe sobre os Institutos Superiores de Educação, considerados os Art. 62 e 63 da Lei 9.394/96 e o Art. $9^{\circ}, \S 2^{\circ}$, alíneas "c" e "h" da Lei 4.024/61, com a redação dada pela Lei 9.131/95. Disponível em:

<http://portal.mec.gov.br/cne/arquivos/pdf/rcp001_99.pdf>. Acesso em: 20 jan. 2017.

BRASIL. Ministério da Educação. Conselho Nacional de Educação. Resolução CNE/CP no. 02 , de 18 de fevereiro de 2002. Institui a duração e a carga horária dos cursos de licenciatura, de graduação plena, de formação de professores da Educação Básica em nível superior. Disponível em: <http://portal.mec.gov.br/cne/arquivos/pdf/CP022002.pdf.>. Acesso:20 jan. 2017.

BRASIL. Ministério da Educação e Cultura. O que é o reuni. 25 de março de 2010. Disponível em: <http://reuni.mec.gov.br/o-que-e-o-reuni.>. Acesso em: 14 abr. 2016.

CAMARGO, A. M. M. de. O princípio da flexibilidade curricular dos cursos de graduação. In: CHAVES, V. L. J.; CABRAL NETO, A.; NASCIMENTO, I. V. (Org.). Políticas de educação superior no Brasil: velhos temas, novos desafios. São Paulo: Xamã, 2009, p. 211-225. 
COIMBRA, L. J. P. Educação para o capital: o projeto pedagógico da Fundação Bradesco de São Luís-MA. 2009. 113 f. Dissertação (Mestrado em Educação) Universidade Federal do Maranhão, São Luís, 2009.

COIMBRA, L. J. P.; SOUSA, A. P. R. de. As licenciaturas interdisciplinares e o processo de expansão das IFES: implicações para a formação de professores. Rev. HISTEDBR Online, Campinas, n. 65, p. 141-159, out. 2015.

DUARTE, N. A individualidade para si: contribuição a uma teoria histórico-crítica da formação do indivíduo. 3. ed. Campinas, SP: Autores Associados, 2013.

FONTANA, J. A história dos homens. Bauru, SP: Ed. da EDUSC, 2004.

FRIGOTTO, G. A produtividade da escola improdutiva: um (re)exame das relações entre educação e estrutura econômico-social capitalista. 9. ed. São Paulo: Cortez, 2010.

FRIGOTTO, G. Os delírios da razão: crise do capital e metamorfose conceitual no campo educacional. In: GENTILI, P. (Org.). Pedagogia da exclusão: o neoliberalismo e a crise da escola pública. 11. ed. Petrópolis, RJ: Vozes, 1995. p. 77-108. (Coleção estudos culturais em educação).

KUENZER, A. Z. Exclusão includente e inclusão excludente: a nova forma de dualidade estrutural que objetiva as novas relações entre educação e trabalho. In: LOMBARDI, J. C.; SAVIANI, D.; SANFELICE, J. L. (Org.). Capitalismo, trabalho e educação: debates contemporâneos 3. ed. Campinas, SP: Autores Associados; HISTEDBR, 2005. p. 77-95.

LIBÂNEO, J. C. Didática. São Paulo: Cortez, 1994.

MAARS, W. L. À guisa de introdução: adorno e a experiência formativa. In: ADORNO, T. W. Educação e emancipação. São Paulo: Paz e Terra, 2011.

MARTINS, L. M. Da formação humana em Marx à crítica da pedagogia das competências. IN: DUARTE, N. (Org.). Crítica ao fetichismo da individualidade. Campinas, SP: Autores Associados, 2004. p. 53-74.

MARTINS, L. M. O desenvolvimento do psiquismo e a educação escolar: contribuições à luz da psicologia histórico-cultural e da pedagogia histórico-crítica. Campinas, SP:

Autores Associados, 2013.

MARX, K. A ideologia alemã. 2. ed. São Paulo: Martins Fontes, 1998. (Clássicos).

MARX, K. Crítica da filosofia do direito de Hegel. São Paulo: Boitempo, 2005.

MARX, K. Manuscritos econômico-filosóficos. São Paulo: Martin Claret, 2005a.

MARX, K. O capital: crítica da economia política: livro I. 21. ed. Rio de Janeiro: Civilização Brasileira, 2003. 
MELLO, G. N. Magistério de $\mathbf{1}^{\mathbf{0}}$ grau: da competência técnica ao compromisso político. 12. ed. São Paulo: Cortez, 1998.

MÉSZÁROS, I. A educação para além do capital. São Paulo: Boitempo, 2005.

NUNES, I. de. M. L. Formação docente e licenciaturas interdisciplinares: o caminho percorrido pela Universidade Federal do Maranhão. Portugal: Ed. da FLUP, 2014.

SANFELICE, J. L. A formação docente e os desafios da profissão. Avesso do Avesso: Revista de Educação e Cultura, Araçatuba, v. 8, n. 8, nov. 2010.

SAVIANI, D; DUARTE, N. A Formação humana na perspectiva histórico-ontológica. In: SAVIANI, D.; DUARTE, N. Pedagogia histórico-crítica e luta de classes na educação escolar Campinas, SP: Autores Associados, 2012. p. 13-36. (Coleção polêmicas do nosso tempo).

SAVIANI, D. Educação socialista, pedagogia histórico-crítica e os desafios da sociedade de classes. In: LOMBARDI, J. C.; SAVIANI, D. (Org.). Marxismo e educação: debates contemporâneos. Campinas, SP: Autores Associados; HISTEDBR, 2005 b.

SAVIANI, D. Escola e democracia: teorias da educação, curvatura da vara, onze teses sobre a educação política. 39. ed. Campinas, SP: Autores Associados, 2007. (Coleção polêmicas do nosso tempo, v. 5).

SAVIANI, D. História da escola pública no Brasil: questões para pesquisa. In: LOMBARDI, J. C.; SAVIANI, D.; NASCIMENTO, M. I. M. (Org.). A escola pública no Brasil: história e historiografia. Campinas, SP: Autores Associados; HISTEDBR, 2005. (Coleção memória da educação).

SAVIANI, D. Pedagogia histórico-crítica: primeiras aproximações. 9. ed. Campinas, SP: Autores Associados, 2005a. (Coleção educação contemporânea).

UNIVERSIDADE FEDERAL DO MARANHÃO. UFMA. Matriz curricular do curso de licenciatura em ciências humanas com ênfase em sociologia. 2017. 1 quadro. (Adaptado pelos autores).

UNIVERSIDADE FEDERAL DO MARANHÃO. UFMA. Pró-Reitoria de ensino. Departamento de Desenvolvimento do Ensino de Graduação. Projeto Pedagógico do Curso de Licenciatura Interdisciplinar em Ciências Humanas/Sociologia - Campus Bacabal. São Luís, 2013.

VÁZQUEZ, A. S. Filosofia da Práxis. 4. ed. Rio de Janeiro, RJ: Paz e Terra, 1977. 


\section{Revista HIISTEXIDBR Dn-lime}

Notas

1 Professor assistente da Universidade Federal do Maranhão- UFMA. Doutorando em Educação pela Universidade Federal Fluminense (UFF). Pesquisador do Grupo de Estudos e Pesquisas: HISTEDBR-MA.

2 Professora assistente da Universidade Federal do Maranhão (UFMA). Doutoranda em Educação pela Universidade Federal Fluminense (UFF). Pesquisadora do Grupo de Estudos e Pesquisas História, Sociedade e Educação no Brasil - HISTEDBR (GT- Maranhão).

${ }^{3}$ No caso da sociedade capitalista, onde a produção está alienada do produtor, ocorre justamente a desumanização do homem, pois o mesmo não se vê como agente produtor/transformador do mundo que o cerca e do qual faz parte.

${ }^{4}$ A categoria da práxis foi muito bem trabalhada por Vázquez (1977), e tem um duplo caráter, pois se configura tanto como interpretação do mundo quanto como um meio para sua superação, para o entendimento da essência da realidade em lugar das aparências.

${ }^{5}$ Também chamada de "Terceira Revolução Industrial", o revolucionar da base produtiva material - originando as tecnologias flexíveis (microinformática, microeletrônica, microbiologia, nanotecnologia, etc.) e a utilização de novas fontes de energia (energia atômica) -, aliada à reestruturação da produção e os novos modelos de organização e gestão do trabalho (toyotismo), tem gerado uma superexploração do trabalhador (SAVIANI, 2005a, p. 244-245), além de desemprego estrutural, com o incremento do trabalho morto em detrimento do trabalho vivo, e a substituição das linhas pelas células de produção.

${ }^{6}$ Aqui fazemos alusão à obra de Newton Duarte, de título: Sociedade do conhecimento ou sociedade das ilusões?

${ }^{7}$ Aqui tomamos como referência o conceito de competência profissional de Mello (1998, p. 43), que integra várias características, dentre as quais: domínio do conhecimento, assim como de sua organização e transmissão; conhecimento de todos os aspectos que compõem a estrutura e o funcionamento da escola, importantes para formar no educador "[...] uma visão relativamente integrada e articulada dos aspectos relevantes mais imediatos de sua própria prática"; uma visão contextualizada de sua prática, que possa articular preparo técnico, organização escolar e resultados obtidos; "“...] uma compreensão mais ampla das relações entre a escola e a sociedade".

8 "Sociedade do Conhecimento", "Sociedade da Informação", "Sociedade de Aprendentes", etc., todas fraseologias que escodem o real significado em que esta sociedade está assentada - a subsunção dos conteúdos cognitivos dos processos de produção da nossa existência ao 'saber-fazer', ao pragmático, ao imediato, ao útil. ${ }^{9}$ A expansão da educação superior foi concebida em três etapas. A chamada Expansão I, que abrange o período de 2003 a 2007, teve como principal meta interiorizar o ensino superior público federal. Por sua vez, o período entre 2008 a 2012, no qual foi implantada a Fase II, foi marcado pela execução do REUNI. Finalmente, em sua terceira Fase, a expansão da educação superior caracteriza-se pela continuidade das propostas anteriores e a sua complementação com iniciativas específicas de desenvolvimento regional. (BALANÇO SOCIAL DO SESU 2003-2014).

${ }^{10}$ As Licenciaturas Interdisciplinares foram concebidas originalmente com o objetivo de formar docentes para o Ensino Fundamental, preferencialmente nas séries finais, nas áreas de Ciências Humanas, Sociais e Filosofia, Ciências da Natureza e Linguagens e Códigos.

${ }^{11}$ Para uma análise mais detalhada do processo de criação das novas licenciaturas interdisciplinares da UFMA ver: COIMBRA; SOUSA (2015).

${ }^{12}$ Tal padrão se tornou convencional nos cursos de licenciatura consagrados a partir das décadas de $1940 \mathrm{e}$ 1950, nos bacharelados complementados pelas disciplinas pedagógicas, em que observamos a dicotomia entre teoria e prática, por meio da separação das disciplinas de conteúdo específicos das áreas de conhecimento das disciplinas pedagógicas e a desarticulação entre a formação acadêmica e a realidade prática.

${ }^{13} \mathrm{O}$ projeto pedagógico das Licenciaturas interdisciplinares elaborado originalmente pela Pró-Reitoria de Ensino da UFMA, em 2010, e aprovado ad referendum do Conselho Universitário (CONSUN) e sem passar pelas instâncias deliberativas competentes, conforme o Regimento Interno da Universidade, previa uma carga horária de 2880 horas e um período de integralização mínimo de três anos. No entanto, por conta das contradições do projeto, que encontrou muita resistência por parte dos professores, e por problemas operacionais quanto à implementação do formato do curso, o mesmo foi reformulado no ano de $2012 \mathrm{em}$ diversos momentos de discussão entre os professores e a Pró-Reitoria de Ensino, resultando em um novo projeto, com alterações pontuais, mas mantendo a mesma concepção de formação, passando a uma carga horária de 3.330 horas, com prazo mínimo de integralização de quatro anos. Entretanto, a formação ministrada 


\section{Revista HIISTEIDBR On-line}

qualificaria o egresso também para a docência no ensino médio em uma das disciplinas específicas de cada área de conhecimento.

${ }^{14}$ Mesmo com o processo de reformulação curricular das LIs, o núcleo de conteúdos da formação pedagógica ficou enfraquecido, com apenas 330 horas, configurando o empobrecimento da formação teórica do professor nas disciplinas de fundamentos e metodologias da educação, em detrimento da formação "prática", que abrande 405 horas de estágio supervisionado e 405 horas de "Prática como componente curricular". (PECC).

${ }^{15}$ No ano de 2015 foi aprovado uma nova reformulação no projeto das LIs admitindo-se a criação de duas habilitações ("ênfases") em cada área do conhecimento, durante o último ano do curso, de modo a habilitar o egresso a ministrar aulas das disciplinas da ênfase no ensino médio. O estudante opta, no ato da seleção, por uma das ênfases que irá cursar.

${ }^{16}$ Conforme o entendimento de Saviani (2005a), a proposta de socialização do saber elaborado é a tradução pedagógica do princípio mais geral da socialização dos meios de produção, que, no modo de produção capitalista, se mantem como monopólio das elites. Nesse sentido, para o autor, a vinculação entre os interesses da classe trabalhadora e a socialização do saber escolar é explícita.

17 O termo "instrumentalização" aqui é utilizado no sentido atribuído por Saviani (2007), como um dos momentos articuladores do processo pedagógico na perspectiva da pedagogia histórico-crítica, ou seja, "Tratase de se apropriar dos instrumentos teóricos e práticos necessários ao equacionamento dos problemas detectados na prática social. [...] Trata-se da apropriação pelas camadas populares das ferramentas culturais necessárias à luta social que se trava diuturnamente para se libertar das condições de exploração em que vivem”. (SAVIANI, 2007, p. 71).

Submetido em: 30/04/2016

Aprovado em: 21/08/2017 